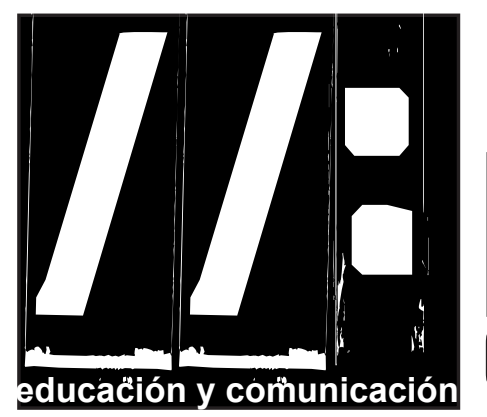

EDITRIAL 11: 9-10 Nov. 2015

implemente, el título del presente número de la revista hachetetepé -http- (ya vamos por el 11), nos seduce. Puede - existir, de lo que estamos convencido, otros títulos más controvertidos, deseados o, inclusive, apegados a la realidad. Pero, no obstante, éste de "Educación y comunicación actual" nos embargó posiblemente por lo de actual. Pensamos en la inmediatez, en lo que nos ha tocado vivir y de lo cual somos agentes y agencias de la contemporaneidad. Vayamos a explicarnos un poco sobre estos dos conceptos: lo de agentes, tal vez, por lo de sujetos activos más que por lo de individuos pasivos. Y lo de agencia por, quizás, la conversión masiva de ser emisor y receptor de una materia prima y primordial como es la información y la comunicación. El siglo XXI, el nuestro, el de referencia no niega lo anterior, cohabitando los mass media con los nuevos medias. Pero se erige sobre un nuevo modelo de comunicación que ha transformado la mayoría de los segmentos de la población. La comunicación, la incomunicación, la discomunicación son elementos que se irradian por la educación y la cotidianeidad. Por ello, podemos empezar a hablar de un nuevo hecho comunicativo (actual).

Dicho esto, lo que acabamos de hacer no es más que una presentación al título que, insistimos, nos ha persuadido desde el principio. Ahora bien, en este momento, cabría hacer alusión e hincapié en los artífices: un dueto hispano-italiano de profesoras universitarias. Beatriz Pérez González de la Universidad de Cádiz y Mihaela Gravila de la Università de Roma. Y vaya por adelantado nuestra gratitud y reconocimiento a un extraordinario trabajo, delicado y sensible con un resultado: el haber generado una visión de lo actual sea en el ámbito de la sociología, la comunicación o la educación. Igualmente, el resultado es lo que ustedes irán a descubrir a partir de la lectura, análisis y reflexión de estas páginas. Un viaje iniciático por aquello que en el título genérico llamábamos de lo actual. La actualidad nos puede encandilar 
o escandalizar, con unas consecuencias verosímiles o inverosímiles. La abrazamos o la rechazamos. Nos pertenece o nos excluye. Pero no deja de ser lo actual. Y, a lo que añadiríamos, que ahí estamos. Somos capaces de tomar conciencia de unos hechos abruptos o encantadores que, probablemente, no nos dejen ver la magnitud de lo actual. La comunicación necesita de la reciprocidad y lo actual no solo lo permite sino que lo incentiva. Es casi inadmisible en lo actual desenvolverse sin una comunicación interactiva. ¿Y la educación? Pues no puede quedar al margen de todo lo anterior. Debe desarrollarse en lo actual y en paralelo con los emergentes procesos de comunicación.

Buen disfrute y, eso, no perdamos del horizonte vital lo de lo actual. Estamos hablando, y hablan, de todos nosotros (también nosotras) y aquí en la revista http número 11 hay una buena muestra de ello. Ojalá les sirva.

Por último, no dudamos en la calidad de los artículos (sean en la sección del monográfico, como en el divulgatio). Vayamos a reconocer la generosidad y experiencia de los autores. Pues, con ellos y sus contribuciones de saber y sensibilidad, todo esto no sería, precisamente, actual.

Con todo, hemos introducido el título del monográfico, las dos coordinadoras, los contenidos de lo que aquí se va a hablar, los autores y no nos olvidamos de los lectores; pues de no hacerlo sería considerado como algo poco elegante. A esta extensa red de narratarios nos gusta llamarlos, cariñosamente, de hacheteteperos. Y sin ustedes cada día, cada número que sale, nuestra revista (que es también la suya) tiene más sentido y nos nutre de ilusión para continuar en esta singladura de compartir el conocimiento para que se torne sabiduría.

Grazie mille; o sea, muchas gracias.

\section{Víctor Amar}

Director de la revista Hachetetepé "http"

(Grupo de Investigación "Educom”. Universidad de Cádiz) 